STUDIES IN POPULAR CULTURE

Leisure, citizenship and working-class men in Britain, 1850-1945

BRAD BEAVEN

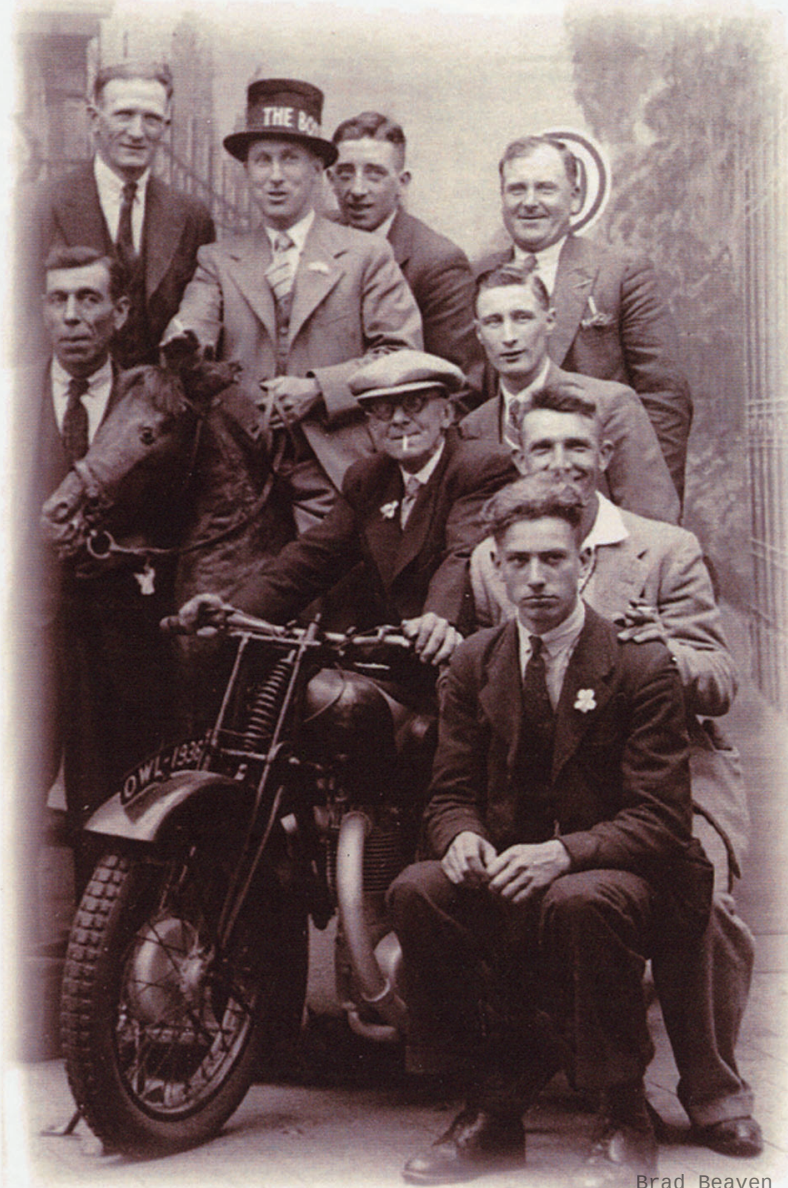

Downloaded from manchesterhive.com at $\odot 4 / 26 / 2023$ 01:10: $02 \mathrm{PM}$ 


\section{Leisure, citizenship and working-class men in Britain, 1850-1945}

\section{MANCHESTER \\ 1824}

Manchester University Press 


\section{STUDIES IN \\ POPULAR \\ CULTURE}

Already published

Working-class organisations and popular tourism, 1840-1970

Susan Barton

The British consumer Co-operative Movement and film, 1890s-1960s

Alan George Burton

Railways and culture in Britain

lan Carter

Relocating Britishness

Stephen Caunce, Ewa Mazierska, Susan Sydney-Smith

and John Walton (eds)

Spiritualism and British society between the wars

Jenny Hazelgrove

Smoking in British popular culture, 1800-2000

Matthew Hilton

Popular culture in London, c. 1890-1918:

the transformation of entertainment

Andrew Horrall

Horseracing and the British, 1919-39

Mike Huggins

Women's leisure in England, 1920-60

Claire Langhamer

Scotland and the music hall, 1850-1914

Paul Maloney

The car in British society: class, gender and motoring, 1896-1939

Sean O'Connell

Films and British national identity: from Dickens to Dad's Army Jeffrey Richards

Looking North: Northern England and the national imagination

Dave Russell

The British seaside holiday: holidays and resorts

in the twentieth century

John K. Walton 


\section{Leisure, citizenship and working-class men in Britain, 1850-1945}

\section{BRAD BEAVEN}

Manchester University Press

Manchester and New York

distributed exclusively in the USA by Palgrave 
Copyright (C) Brad Beaven 2005

The right of Brad Beaven to be identified as the author of this work has been asserted by him in accordance with the Copyright, Designs and Patents Act 1988.

Published by Manchester University Press

Oxford Road, Manchester MI3 9NR, UK

and Room 400, 175 Fifth Avenue, New York, NY 10010, USA

www.manchesteruniversitypress.co.uk

Distributed exclusively in the USA by

Palgrave, 175 Fifth Avenue, New York,

NY 10010, USA

Distributed exclusively in Canada by

UBC Press, University of British Columbia, 2029 West Mall,

Vancouver, BC, Canada V6T IZ2

British Library Cataloguing-in-Publication Data

A catalogue record for this book is available from the British Library

Library of Congress Cataloging-in-Publication Data applied for

ISBN 0719060273 hardback

EAN 9780719060274

First published 2005

$\begin{array}{llllllllll}14 & 13 & 12 & 11 & 10 & 09 & 08 & 07 & 06 & 05\end{array}$

10987654321

Typeset in Monotype Garamond

by Illuminati, Grosmont

Printed in Great Britain

by Biddles Ltd, King's Lynn 